\title{
Pengaruh Pemberian Probiotik Pada Media Pemeliharaan Terhadap Kualitas Air Dan Pertumbuhan Benih Ikan Baung (Mystus Nemurus)
}

\section{Effect of Probiotics on Water Quality and Seed Growth of Baung Fish (Mystus Nemurus)}

\author{
Sondang Rosnaria Purba ${ }^{1}$, Cut Mulyani ${ }^{1}$, Andika Putriningtias ${ }^{1}$ \\ ${ }^{1}$ Program Studi Akuakultur Fakultas Pertanian Universitas Samudra, Jln, Meurandeh, Langsa Lama, Kota \\ Langsa \\ Corresponding author: sondangpurba4@gmail.com
}

Submitted: 18 March 2021 Revised: 24 August 2021 Accepted: 23 September 2021 Publish: 30 October 2021

\begin{abstract}
Abstrak
Ikan banung merupakan ikan asli Indonesia yang terdistribusi di perairan Jawa, Sumatera dan Kalimantan. Kegiatan budidaya pada ikan ini mulai banyak dikembangkan, meskipun informasi sejauh ini memiliki laju pertumbuhan yang lambat. Penelitian ini dilakukan bertujuan untuk mengetahui pengaruh pemberian probiotik pada media pemeliharaan terhadap kualitas air dan pertumbuhan benih ikan baung (Mystus nemurus). Rancangan yang digunakan dalam penelitian ini adalah Rancangan Acak Lengkap dengan 4 perlakuan 3 ulangan. Perlakuan yang diberikan adalah perbedaan jumlah probiotik yang ditambahkan yaitu yang terdiri dari perlakuan tanpa penambahan probiotk, perlakuan dengan penambahan probiotik sebanyak 0,5 ml/L, $1 \mathrm{ml} / \mathrm{L}, 1,5 \mathrm{ml} / \mathrm{L}$. Hasil penelitian menunjukkan bahwa kualitas air pada masa penelitian tidak berpengaruh dan menghasilkan pertumbuhan panjang mutlak $6,30 \mathrm{~cm}$, pertumbuhan berat mutlak 7,60 gr, survival rate $100 \%$, laju pertumbuhan spesifik 4,78\% dan rasio konfersi pakan $3,3 \%$.
\end{abstract}

Kata kunci : Ikan baung, kualitas air, probiotik.

\section{Abstract}

The baung fish is a native Indonesian fish that is spread in the waters of Java, Sumatra, and Kalimantan. This fish has begun to be widely cultivated in the traditional systems, with a slow growth rate. This research was conducted to find out the effect of probiotics administration on maintenance media on water quality and growth of baung fish seed (Mystus nemurus). The design used in this study was a Complete Randomized Design with 4 treatments of 3 repeats. The treatment given is the difference in the amount of probiotics added that consists of treatment without the addition of probiotk, treatment with the addition of probiotics as much as $0.5 \mathrm{ml} / \mathrm{L}, 1 \mathrm{ml} / \mathrm{L}, 1.5 \mathrm{ml} / \mathrm{L}$. The results showed that water quality during the study had no effect and resulted in absolute long growth of $6.30 \mathrm{~cm}$, absolute weight growth of $7.60 \mathrm{gr}$, survival rate of $100 \%$, specific growth rate of $4.78 \%$ and feed confetti ratio of $3.3 \%$.

Keywords: Baung fish, water quality, probiotics.

\section{PENDAHULUAN}

Ikan baung (Mystus nemurus) adalah salah satu ikan asli perairan Indonesia. Ikan baung hanya terdapat di perairan-perairan tertentu seperti di Pulau Sumatera, Jawa dan Kalimantan. Namun, untuk mendapatkan ikan baung 200 g membutuhkan waktu yang lama yaitu sekitar 5 - 6 bulan pemeliharaan (Sasmi, 2015). Berbagai cara digunakan untuk mengatasi permasalahan tersebut, misalnya penggunaan antibiotik untuk pengobatan ikan yang sakit karena mikroba patogen. Akan tetapi, penggunaan antibiotik pada sistem budidaya akan mengakibatkan munculnya strain-strain bakteri yang resisten terhadap antibiotik ke dalam perairan (Setijahningsih dkk., 2011). Aplikasi probiotik telah banyak digunakan pada ikan ikan dengan laju pertumbuhan yang lambat. Probiotik merupakan mikroba hidup (bakteri) 
yang menguntungkan bagi inang dengan meningkatkan keseimbangan mikroba saluran pencernaan. Saluran pencernaan merupakan salah satu pintu masuk yang paling umum bagi bakteri untuk menyerang ikan, mengingat habitat ikan pada perairan yang mengandung berbagai bakteri yang berpotensi patogen (Gatlin dan Peredo, 2012). Selanjutnya, aplikasi probiotik pada media pemeliharaan bertujuan untuk memperbaiki kualitas air melalui biodegradasi, untuk menjaga keseimbangan perairan dengan menekan bakteri patogen (Mansyur dan Tangko, 2008). Pemberian probiotik pada media pemeliharaan diharapkan dapat untuk memperbaiki kualitas air dengan mengurai sisa-sisa pakan dan feses ikan (Khasani, 2007). Tujuan dari penelitian ini adalah mengetahui pengaruh pemberian probiotik pada media pemeliharaan terhadap kualitas air dan pertumbuhan benih ikan baung (Mystus nemurus).

\section{Metode Penelitian}

\section{Waktu dan tempat penelitian}

Penelitian ini dilakukan pada bulan November - Desember 2020 di Green House Universitas Samudra, Kota Langsa, Aceh.

\section{Rancangan penelitian}

Penelitian ini menggunakan metode eksperimental rancangan acak lengkap (RAL) non faktorial dengan 4 perlakuan dengan 3 ulangan. Dimana perlakuan kontrol (P0) tanpa penambahan probiotik $\left(\mathrm{EM} 4^{\mathrm{TM}}\right)$, perlakuan pertama (P2); penambahan probiotik $0,5 \mathrm{ml} / \mathrm{L}$, (P3); $1 \mathrm{ml} / \mathrm{L}$, dan (P4); 1,5 ml/L dengan padat tebar masing masing 10 ekor/ akuarium $(25 \mathrm{~cm} \times 25 \mathrm{~cm} \times 30 \mathrm{~cm}$ dengan tinggi air $18 \mathrm{~cm}$ ).

\section{Kualitas Air}

Suhu air diukur dengan termometer, DO meter untuk mengukur oksigen terlarut, $\mathrm{pH}$ air diukur dengan $\mathrm{pH}$ meter dan amoniak diukur menggunakan test $\mathrm{NH}_{3}$.

Parameter yang diamati

Survival rate (SR)

Kelulusan hidup ikan dihitung dengan rumus menurut Effendie,(2002) sebagai berikut :

$$
\mathrm{SR}=\frac{N t}{N o} \times 100 \%
$$

Keterangan :

$$
\begin{aligned}
\mathrm{SR}= & \text { Kelangsungan hidup }(\%) \\
\mathrm{Nt}= & \text { Jumlah benih yang hidup pada } \\
& \text { akhir percobaan (ekor) } \\
\mathrm{No}= & \text { Jumlah benih yang hidup pada } \\
& \text { awal percobaan }
\end{aligned}
$$

\section{Pertumbuhan Berat Mutlak}

Pertumbuhan mutlak dihitung dengan menggunakan rumus Effendie (2002) sebagai berikut :

$$
\mathbf{W}=\mathbf{W t}-\mathbf{W o}
$$

Keterangan :

$\mathrm{W}=$ Pertumbuhan berat mutlak $(\mathrm{g})$

$\mathrm{Wt}=$ Berat rata-rata akhir $(\mathrm{g})$

$\mathrm{Wo}=$ berat rata-rata awal $(\mathrm{g})$

\section{Pertumbuhan Panjang Mutlak}

Pertumbuhan panjang mutlak dapat dihitung menggunakan rumus:

$$
\mathbf{P}=\mathbf{P t}-\mathbf{P o}
$$

Keterangan :

$\mathrm{P}=$ Pertumbuhan panjang mutlak (cm)

$\mathrm{Pt}=$ Panjang ikan akhir pemeliharaan $(\mathrm{cm})$

Po $=$ Panjang ikan awal pemeliharaan $(\mathrm{cm})$ 


\section{Laju Pertumbuhan Spesifik}

Laju pertumbuhan spesifik dihitung berdasarkan rumus :

\section{SGR $=[($ In Wt-In Wo $) / T] \times 100 \%$}

Keterangan :

Wt : bobot ikan pada hari ke-t

Wo: bobot ikan awal penelitian

$\mathrm{T}$ : waktu pemeliharaan (hari)

SGR : Laju pertumbuhan spesifik

Rasio Konfersi Pakan (FCR)

Rasio konfersi pakan (FCR) dihitung berdasarkan rumus:

$$
\text { FCR }=\frac{\text { Total pakan }(\text { gram })}{\text { Total biomass }(\text { gram })}
$$

\section{HASIL DAN PEMBAHASAN}

Kelulushidupan ikan Baung

Rata-rata survival rate dari benih ikan baung memiliki nilai yang berbeda dari masing masing perlakuan. Selanjutnya, pemberian probiotik pada media pemeliharaan pada perairan berpengaruh nyata $(\mathrm{P}<0.05)$ terhadap laju pertumbuhan dan kelangsungan hidup benih ikan baung (Tabel 1). Berdasarkan hasil uji Duncan menunjukkan bahwa kelulushidupan benih ikan baung yang telah diberi probiotik berkisar antara 86,67\% $100 \%$. Dimana, SR tertinggi terdapat pada perlakuan P3 yaitu sebesar 100,0 \pm $.00^{\mathrm{b}} \%$, sedangkan SR terendah yaitu pada kontrol (P1) dan P2 dengan nilai yang sama yaitu sebesar 86,67 $\pm 3.33^{\mathrm{a}}$ $\%$, sedangkan $\mathrm{P} 4$ sebesar 90,00 \pm $5.77^{\mathrm{ab}} \%$. Tingginya SR pada perlakuan P3 dibandingkan dengan perlakuan lainnya disebabkan karena kualitas air yang baik dan sesuai untuk kehidupan ikan (Lisna dan Insulistyowati, 2015). Selanjutnya, tingginya nilai SR pada perlakuan P3 disebabkan pemberian probiotik yang sesuai dan berkala setiap seminggu sekali, shingga membantu kondisi ekosistem air yang ideal dan baik dalam hal efisiensi penyerapan pakan dan proses nitrifikasi. Selain itu, probiotik mampu meningkatkan imun pada inang yang dibudidayakan (Azhar, 2018).

Tabel 1. Analisis pertumbuhan ikan Baung (Mystus nemurus)

\begin{tabular}{|c|c|c|c|c|}
\hline Parameter & P1 & $\mathrm{P} 2$ & P3 & $\mathrm{P} 4$ \\
\hline SR (\%) & $86,67 \pm 3.33^{\mathrm{a}}$ & $86,67 \pm 3.33^{\mathrm{a}}$ & $100 \pm .00^{b}$ & $90 \pm 5.77^{\mathrm{ab}}$ \\
\hline $\begin{array}{l}\text { Pertumbuhan berat mutlak } \\
\text { (g) }\end{array}$ & $4.23 \pm .63^{\mathrm{a}}$ & $4.68 \pm .78^{\mathrm{a}}$ & $7.60 \pm .26^{b}$ & $5.64 \pm .38^{\mathrm{b}}$ \\
\hline $\begin{array}{l}\text { Pertumbuhan panjang } \\
\text { mutlak }(\mathrm{cm})\end{array}$ & $4.23 \pm .23^{\mathrm{a}}$ & $4.56 \pm .35^{\mathrm{a}}$ & $6.30 \pm .05^{\mathrm{c}}$ & $5.36 \pm .06^{b}$ \\
\hline $\operatorname{SGR}(\%)$ & $3.54 \pm .24^{\mathrm{a}}$ & $4.12 \pm .33^{\mathrm{ab}}$ & $4.78 \pm .20^{\mathrm{b}}$ & $4.46 \pm .25^{\mathrm{b}}$ \\
\hline $\operatorname{FCR}(\%)$ & $6.13 \pm .81^{\mathrm{b}}$ & $5.66 \pm .99^{\mathrm{b}}$ & $3.30 \pm .11^{\mathrm{a}}$ & $4.89 \pm .32^{\mathrm{ab}}$ \\
\hline
\end{tabular}

Keterangan: Huruf yang sama pada kolom yang sama menunjukkan pengaruh perlakuan yang berbeda nyata $(\mathrm{P}<0.05)$. Nilai yang tertera merupakan nilai rata-rata dan standart error.

baung yang telah diberi probiotik

Pertumbuhan Berat Mutlak (PBM)

Pemberian probiotik pada media pemeliharaan pada kualitas air memberi pengaruh nyata $(\mathrm{P}<0.05)$ pertumbuhan benih ikan baung. Hasil uji Duncan pertumbuhan berat mutlak benih ikan menunjukkan bahwa perlakuan P3, dan P4 tidak berbeda nyata, namun berbeda nyata dengan kontrol (P1) dan P2. Pertumbuhan berat mutlak benih ikan baung paling tinggi diperoleh pada perlakuan P3 sebesar $7.60 \pm .26^{\mathrm{b}} \mathrm{g}$ dan nilai yang terendah yaitu pada kontrol 
(P1) sebesar $4.23 \pm .63^{\mathrm{a}}$ g, sedangkan perlakuan P2 dan P4 masing-masing sebesar $4.68 \pm .78^{\mathrm{a}} \mathrm{g}$ dan $5.64 \pm .38^{\mathrm{b}} \mathrm{g}$ (Tabel 1). Hal ini menunjukkan bahwa pertumbuhan berat mutlak benih ikan baung dipengaruhi oleh pemberian probiotik. Probiotik dapat menyebabkan tingginya aktivitas bakteri pada saluran pencernaan dan perbedaan jumlah bakteri probiotik yang terkandung dalam pakan atau air dapat mempengaruhi laju pertumbuhan ikan (Hendri, 2012).

\section{Pertumbuhan Panjang Mutlak (PPM)}

Pemberian probiotik juga perpengaruh nyata $(\mathrm{P}<0.05)$ terhadap pertumbuhan panjang mutlak benih ikan baung, meskipun memiliki nilai yang berbeda pada masing masing perlakuan. Hasil uji Duncan pertumbuhan menunjukkan bahwa kontrol (P1) dan P2 tidak berbeda nyata, namun berbeda nyata dengan kontrol $\mathrm{P} 4$ sementara $\mathrm{P} 3$ tidak berbeda nyata dengan perlakuan lainnya. Pertumbuhan panjang mutlak benih ikan baung paling tinggi pada penelitian ini hampir sama dengan pola pertumbuhan berat yaitu diperoleh pada perlakuan P3 sebesar $6.30 \pm .10^{\mathrm{c}} \mathrm{cm}$ dan nilai yang terendah yaitu pada kontrol (P1) sebesa r $4.23 \pm .40^{\mathrm{a}} \mathrm{cm}$, sedangkan perlakuan P2 dan P4 masing-masing sebesar $4.56 \pm .61^{\mathrm{a}} \mathrm{cm}$ dan $5.36 \pm .11^{\mathrm{b}}$ $\mathrm{cm}$ (Tabel 1). Hal ini menunjukkan bahwa pertumbuhan panjang mutlak benih ikan baung signifikan dengan pertumbuhan bobot. Panjang mutlak merupakan selisih panjang akhir dengan panjang awal benih ikan selama masa pemeliharaan.
Hal ini menunjukkan dengan bertambahnya bobot benih ikan maka bertambah pula panjang ikan. Penambahan probiotik mampu memperbaiki kualitas air juga bekerja dalam saluran pencernaan ikan, sehingga pertumbuhan ikan meningkat (Gatesoupe 1999; Lisna dan Sulistyowati, 2015). Mulyadi (2011), menjelaskan aktivitas bakteri dalam pencernaan akan berubah dengan cepat apabila ada mikroba yang masuk melalui pakan atau air, yang mampu mengoptimalkan pakan.

\section{Laju Pertumbuhan Spesifik (SGR)}

Laju pertumbuhan spesifik (SGR) benih ikan baung berkisar antara 3,54 $4,46 \%$ /hari benih ikan baung (Tabel 1). Analisis sidik ragam menunjukkan bahwa dengan pemberian probiotik pada media pemeliharaan terhadap kualitas air dan pertumbuhan benih ikan baung berpengaruh nyata $(\mathrm{P}<0.05)$ terhadap laju pertumbuhan spesifik benih ikan baung. Berdasarkan hasil uji Duncan diketahui bahwa laju pertumbuhan spesifik benih ikan baung terdapat pada perlakuan P3 dengan penambahan dosis probiotik sebanyak $1 \mathrm{ml} / \mathrm{L}$ yaitu sebesar $4.78 \pm .20^{\mathrm{b}} \% / \mathrm{hari}$, sedangkan laju pertumbuhan spesifik terendah pada perlakuan kontrol (P1) yaitu sebesar $3.54 \pm .24^{\mathrm{a}} \%$ /hari.

Probiotik meningkatkan laju pertumbuhan spesifik benih ikan baung jika dibandingkan pemeliharaan tanpa probiotik (Primashita dan Rahardja, 2017). Rendahnya laju pertumbuhan spesifik pada kontrol (P1) dibandingkan dengan perlakuan lainnya diduga karena penurunan kualitas air. Hal tersebut 
sesuai dengan pernyataan Lisna dan Insulistyowati (2015) bahwa tingginya kadar amonia dapat mempengaruhi pertumbuhan ikan, menyebabkan ikan stres, menurunnya nafsu makan, timbulnya penyakit dan menyebabkan kematian. Selain itu perlakuan kontrol yang tidak ditambahkan probiotik pada media pemeliharaan sehingga populasi bakteri yang dapat mengoksidasi bahan organik sedikit.

\section{Rasio konfersi pakan (FCR)}

Analisis sidik ragam menunjukkan bahwa dengan pemberian probiotik pada media pemeliharaan terhadap kualitas air dan pertumbuhan benih ikan baung berpengaruh nyata $(\mathrm{P}<0.05)$ terhadap Rasio konfersi pakan (FCR) benih ikan baung. Berdasarkan hasil uji Duncan diketahui bahwa rasio konfersi pakan benih ikan baung terendah terdapat pada perlakuan P3 dengan penambahan dosis probiotik sebanyak $1 \mathrm{ml} / 1$ yaitu sebesar $3.30 \pm .11^{\mathrm{a}} \%$, sedangkan rasio konfersi pakan tertinggi pada perlakuan kontrol (P1) yaitu sebesar $6.13 \pm .81^{\mathrm{b}} \%$. Dalam hal ini menunjukkan bahwa pemberian probiotik pada media pemeliharaan berpengaruh dalam peningkatan rasio konfersi pakan benih ikan baung jika dibandingkan dengan media pemeliharaan yang tanpa diberikan probiotik. Pada perlakuan P3 dengan penambahan probiotik sebanyak $1 \mathrm{ml} / \mathrm{L}$ didapatkan hasil rasio konversi pakan paling rendah dibandingkan dengan perlakuan kontrol yang tanpa penambahan probiotik pada media pemeliharaan.

\section{Kualitas Air}

Kualitas air merupakan suatu ukuran terpenting yang harus dijaga oleh pelaku budidaya untuk mempertahankan proses budidaya yang baik bagi komoditas benih ikan baung yang dibudidaya. Maka daripada itu kondisi kualitas air pada saat penelitian harus dijaga dalam keadaan yang optimal. Hasil pengukuran kualitas air selama penelitian dapat dilihat pada (Tabel 2).

Tabel 2. Data kualitas air media pemeliharaan benih ikan baung selama penelitian

\begin{tabular}{lcccc}
\hline \multicolumn{5}{c}{ Kualitas Air } \\
\hline Perlakuan & $\begin{array}{c}\text { Oksigen terlarut } \\
(\mathrm{mg} / \mathrm{L})\end{array}$ & $\mathrm{pH}$ & $\begin{array}{l}\text { Suhu } \\
\left({ }^{\circ} \mathrm{C}\right)\end{array}$ & $\begin{array}{c}\text { Amoniak } \\
(\mathrm{mg} / \mathrm{L})\end{array}$ \\
P1 & 4,8 & 7,06 & 28,6 & 1,12 \\
P2 & 4,7 & 7,42 & 29,4 & 1,10 \\
P3 & 4,9 & 7,69 & 29,2 & 0,75 \\
P4 & 4,6 & 6,80 & 28,9 & 0,85 \\
\hline
\end{tabular}

Kualitas air dari setiap perlakuan hampir sama, baik dari kadar DO, kadar $\mathrm{pH}$, suhu dan kadar amoniak (Tabel 2). Hasil pengukuran suhu pada setiap perlakuan berkisar antara $28,6-29,4^{\circ} \mathrm{C}$, kisaran pH adalah 6,80- 7,69. Pada pengukuran DO yaitu berkisar antara 4,6 -4,9 mg/L dan untuk kadar amoniak yaitu berkisar antara $0,75-1,12 \mathrm{mg} / \mathrm{L}$. Sesuai dengan pernyataan dari Amri dan Khairuman (2011) yang menyatakan bahwa suhu normal habitat ikan baung adalah $27-33^{\circ} \mathrm{C}$, derajat keasaman $(\mathrm{pH})$ antara 6,5 - 8,0 kandungan oksigennya minimal 4 serta amoniaknya berkisar antara $0,13-0,88 \mathrm{ppm}$. 
Journal of Aquaculture Science

DOI: https://doi.org/10.31093/joas.v6i2.143

\section{KESIMPULAN}

Pemberian probiotik pada perairan berpengaruh nyata $(\mathrm{P}<0,05)$ terhadap tingkat kelulushidupan, pertumbuhan berat mutlak, pertumbuhan panjang mutlak dan laju pertumbuhan spesifik. Dosis $1 \mathrm{ml} / \mathrm{L} \quad$ (P3) memiliki laju pertumbuhan terbaik dibanding semua perlakuan.

\section{DAFTAR PUSTAKA}

Azhar, F. (2018). Aplikasi Bioflok yang dikombinasikan dengan Probiotik untuk Pencegahan Infeksi Vibrio parahaemolyticus pada Pemelihaaran. Journal of Aquaculture Science, 3(1), 128-137.

Effendie, I. 2006. Pengantar Akuakultur. Penebar Swadaya. Jakarta.

Gatlin, II. D.M. and Peredo, A.M. 2012. Prebiotics and probiotics: Definitions and applications. Southern Regional Aquaculture Center (SRAC), Publication No. 4711: 1-8. Texas A \& M University.

Ahmad, Hendri., Iskandar, Nia Kurniawati. 2012. Pemberian Probiotik Dalam Pakan Terhadap Pertumbuhan Lele Sangkuriang (Clarias gariepinus) Pada Pendederan $l l$. Jurnal Perikanan dan Kelautan.

Khasani, I. 2007. Aplikasi probiotik menuju sistem budidaya perikanan berkelanjutan. Media Akuakultur, 2 (2): 86-90.

Lisna dan Insulistyowati. 2015. Potensi Mikroba Probiotik_Fm Dalam Meningkatkan Kualitas Air Kolam Dan Laju Pertumbuhan Benih Ikan Lele Dumbo (Clarias gariepinus). Universitas jambi,Jambi.

Mansyur, A. dan Tangko, A. M. 2008. Probiotik: Pemanfaatannya untuk pakan ikan berkualitas rendah. Media Akuakultur, 3 (2): 145-149.

Mulyadi, A.E. 2011. Pengaruh Pemberian Probiotik Pada Pakan Komersil Terhadap Laju Pertumbuhan Benih Ikan Patin Siam (Pangasius hypophthalamus). Skripsi. Fakultas Perikanan dan Kelautan Unpad : Jatinangor.

Primashita, A. H., \& Rahardja, B. S. (2017). Pengaruh Pemberian Probiotik Berbeda dalam Sistem Akuaponik terhadap Laju Pertumbuhan dan Survival Rate Ikan
Lele (Clarias sp.). Journal of Aquaculture Science, 1(1), 1-9.

Sasmi, H., Hendrik, dan Hendri, R. 2015. Analisis Usaha Budidaya Ikan SistemKeramba Jaring Apung (KJA) di Desa Sungai Paku Kecamatan Kampa Kiri Kabupaten Kampar Provinsi Riau. [Skripsi]. Fakultas Perikanan danIlmu Kelautan. Universitas Riau, Riau. 12 hlm.

Setijahningsih, L., Nafiqoh, N., dan Nugroho, E. 2011. Pengaruh pemberian probiotik pada pemeliharaan benih ikan nila (Oreochromis niloticus). Prosiding Forum Inovasi Teknologi Akuakultur, 745-752. 